\title{
sciendo
}

\section{EFFECTS OF REARING SYSTEM AND FEEDING INTENSITY ON THE FATTENING PERFORMANCE AND SLAUGHTER VALUE OF YOUNG CROSSBRED BULLS*}

\author{
Zenon Nogalski ${ }^{1 \star}$, Paulina Pogorzelska-Przybyłek ${ }^{1}$, Monika Sobczuk-Szul ${ }^{1}$, Cezary Purwin², Monika \\ Modzelewska-Kapituła ${ }^{3}$
}

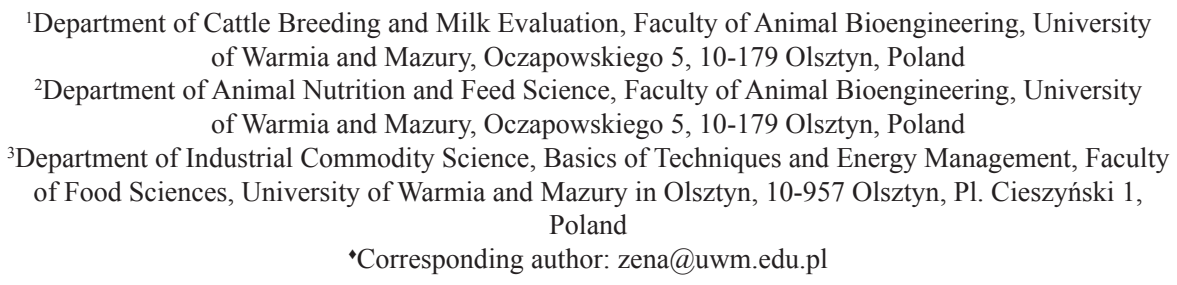

\begin{abstract}
The aim of this study was to determine the effects of rearing system and feeding intensity on the fattening performance and slaughter value of 38 young crossbred bull calves. The calves were raised naturally with nurse cows (NC) or were fed milk replacer (MF) until 150 days of age. During the rearing period the $\mathrm{NC}$ calves were healthier and had higher average daily gain (by $0.15 \mathrm{~kg}$ ) compared to the MF calves. After a 30-day transition period, the animals were fattened in intensive (I) and semi-intensive (SI) systems from 181 to 560 days of age. During the fattening period, the bulls were fed ad libitum a total mixed ration (TMR) composed of grass silage and concentrate. The concentrate to silage ratio, on a DM basis, was 25:75 (SI) and 40:60 (I). The MF calves had lower $\mathrm{BW}$ at the end of the fattening period compared to the $\mathrm{NC}$ calves but the rearing system had no effects on daily gain during the fattening period. Compensatory growth was not observed during fattening. During the fattening period, a higher proportion of concentrate in the ration contributed to higher feed intake, higher feed efficiency and more desirable carcass characteristics. Three-rib cuts from the carcasses of the I bulls had significantly $(P<0.05)$ higher fat content and lower bone content compared to the carcasses of the SI bulls. The longissimus thoracis muscle of the I bulls had higher $(\mathbf{P}<\mathbf{0 . 0 1})$ intramuscular fat content compared to the SI bulls.
\end{abstract}

Key words: beef, nurse cow, crossbred, carcass characteristics, cattle fattening

In the countries where beef cattle populations are small, beef is produced in dairy cattle herds. Beef production is based mainly on young bulls, culled cows and, to

*This research was performed as part of Project no. POIG.01.03.01-00-204/09 Optimizing of Beef Production in Poland in accordance with the "From Farm to Fork" Strategy co-financed by the European Regional Development Fund under the Innovative Economy Operational Program 2007-2013. 
a lesser extent, heifers (Nogalski et al., 2014 a). In order to receive higher prices for calves, selected dairy cows and heifers are inseminated with the semen of beef bulls (Purwin et al., 2016). Several-day-old calves are purchased by farmers who specialize in cattle fattening. Dairy $\times$ beef crosses are preferred due to their higher fattening performance and more desirable carcass characteristics compared with pure dairy breeds (Nogalski et al., 2013; Huuskonen et al., 2014).

The calves are usually reared with the use of automatic computer-controlled calf feeding machines. Automatic feeders have the advantage of mixing and delivering warm milk to the calf several times a day according to a set program, and very low labor requirements $-80 \%$ saving compared with twice day feeding. Calves kept in group pens are characterized by higher body weight (BW) gains than those kept in individual pens (Bernal-Rigoli et al., 2012). The disadvantage of automatic feeders is their high cost. Increased litter moisture and a higher incidence of pneumonia are more frequently encountered in calves housed in groups (Wielgosz-Groth et al., 2017). Large numbers of calves in one group and feeding all calves from the same teat increase the risk of cross infection (Klein-Joebstl et al., 2015). Although the suckling of own mother is regarded as the most natural suckling system, farmers often adapt their suckling systems to calves suckling nurse cows. This solution is particularly popular in the rearing of calves produced by mating dairy cows with beef bulls on small farms. In such a rearing system, a nurse cow feeds her own calf and an extra calf (Vaarst et al., 2001). According to Wolcott et al. (2010), the duration of natural suckling (age at weaning) has no influence on the post-weaning growth rate, feed efficiency or carcass quality. However, it is generally recognized that severe pre-weaning nutritional restriction limits the capacity of cattle to exhibit compensatory growth and achieve equivalent weight for age in later life (Hearnshaw, 1997).

Intensive feeding and individual housing during the first three weeks of calves' life have positive long-term effects on subsequent performance (Maccari et al., 2015). Reddy et al. (2017) found that metabolic imprinting in response to nutritional stimulation during early life through the application of readily digestible high energy diets for calves, altered meat quality parameters in later life, in particular fatness scores. Intensive feeding requires larger amounts of more expensive feeds, which increases the overall fattening cost. A diet based on silage supplemented with concentrate prolongs fattening and increases the age at slaughter, which may negatively influence the sensory characteristics of beef, in particular tenderness (Bures and Barton, 2012). Therefore, the objective of this study was to determine the effects of rearing system and feeding intensity on the fattening performance and slaughter value of young crossbred (Polish Holstein-Friesian $\times$ Hereford) bulls.

\section{Material and methods}

The experiment was approved by the Local Ethics Committee for Animal Experimentation at the University of Warmia and Mazury in Olsztyn (Decision No. 121/2010). 


\section{Animals and feeding}

The experimental materials comprised 40 young crossbred bulls produced by mating Polish Holstein Friesian (PHF) cows to Hereford (HH) bulls (the semen of 12 bulls was used). Calves were purchased at 4 to 7 days of age, after the colostrum feeding period when they were fed from nipple buckets. The bull calves were purchased from 18 different farms. The animals were placed in a calf rearing facility at the Agricultural Experiment Station in Bałcyny. After one week of observation, healthy calves were semi-randomly divided into two groups, based on BW. The first group (MF, 20 bulls) was raised in a group pen (Table 1). The calves were milkfed with milk replacer administered via teats from automated milk-feeding stations (Westfalia Surge). Milk replacer allowance is shown in Table 1. The second group (NC, 20 bulls) was raised in a group pen with nurse cows. Nurse cows were 10 midlactation Holstein-Friesian cows culled from a dairy cattle herd. The cows were fed ad libitum grass silage supplemented with $2 \mathrm{~kg}$ of concentrate. During the first one or two days, two calves stayed in individual pens with nurse cows (Vaarst et al., 2001). As soon as they learned to suckle, the calves and nurse cows were transferred to a group pen. At 3 to 4 weeks of age, the calves were disbudded by cauterization. At 6 weeks of age, the calves were vaccinated against anaerobic infections with the Clostrivax vaccine. During the rearing period, calves of both groups were kept in pens on deep litter (straw), with free access to outdoor runs with roofs. In the NC group, floor area per nurse cow +2 calves was $12 \mathrm{~m}^{2}$ and in the MF group, floor area per calf was $2.5 \mathrm{~m}^{2}$. The animals were weighed once a month. The calves of both groups had free access to concentrates, meadow hay and water. In the MF group, calves were fed milk replacer until 150 days of age and in the NC group, calves were allowed to suckle nurse cows until 150 days of age. All calves remained under constant veterinary care. During the rearing period, 8 disease cases were recorded in the MF group ( 5 cases of respiratory tract disease and 3 cases of diarrhea), and two calves died (one death due to respiratory disease and one death due to diarrhea). In the NC group, 3 disease cases were noted (1 case of respiratory tract disease and 2 cases of diarrhea). After weaning, young bulls were transferred to the Animal Research Laboratory equipped with the Roughage Intake Control (RIC) system and the automatic animal weighing system (Insentec, Marknesse, Netherlands). Feed intake and the growth rate of animals were determined on an individual basis. Experimental fattening, which lasted from 181 to 560 days of age, was preceded by a 30-day transition period during which the animals were adapted to finishing diets. Within the two rearing systems, the bulls were semi-randomly divided into two subgroups based on weight. As a result, 38 bulls were kept in four identical pens on deep litter. The animals were fattened in intensive (I) and semi-intensive (SI) systems, and they were fed ad libitum a total mixed ration (TMR) composed of grass silage and concentrate (Tables 2 and 3). The concentrate to silage ratio, on a DM basis, was 25:75 (SI) and 40:60 (I) (Table 3). Fattening intensity was defined as the proportion of concentrate energy in relation to the net energy requirements according to the National Institute of Agronomical Research (INRA) at the beginning of the experiment. It was assumed that at the beginning of fattening, the concentrate would satisfy $50 \%$ and $30 \%$ of the energy requirements of bulls (according to INRA recommendations) 
in the intensive and semi-intensive fattening systems, respectively. When the bulls reached $\mathrm{BW}$ of $300 \mathrm{~kg}$, concentrate composition was modified due to a declining ratio of protein to energy related to age. Bulls with BW below $300 \mathrm{~kg}$ were fed a TMR containing concentrate I (triticale $-71 \%$, rapeseed meal $-25 \%$ and premix $-4 \%$ ), and bulls with BW above $300 \mathrm{~kg}$ were fed a TMR containing concentrate II (triticale $-77 \%$, rapeseed meal $-19 \%$ and premix $-4 \%$ ).

Table 1. Experimental design

\begin{tabular}{|c|c|c|c|}
\hline \multirow{2}{*}{$\begin{array}{c}\text { Experimental period } \\
\text { Calf rearing } \\
\end{array}$} & \multicolumn{3}{|c|}{ Production system } \\
\hline & Milk-feeder (MF) & Nurs & e cow (NC) \\
\hline \multirow[t]{2}{*}{$7-150$ days of age } & $\begin{array}{l}\text { The daily dose of liquid feed }{ }^{1} \text { was: } \\
\text { 8L between weeks two and four, } \\
6 \mathrm{~L} \text { between weeks five and seven, } \\
\text { 4L between weeks eight and eleven, } \\
\text { 3L from week eleven to reaching } 130 \mathrm{~kg} \mathrm{BV}\end{array}$ & Calves reared & $\begin{array}{l}0 \text { bulls } \\
10 \text { nurse cows }\end{array}$ \\
\hline & Unlimited access to concentrate ${ }^{2}$, hay and w & ater & \\
\hline $151-180$ days of age & Grass silage - ad libitum, concentrate - & $2 \mathrm{~kg}$, unlimited & access to water \\
\hline Fattening & Semi-intensive (SI) & Intensive (I) & Semi-intensive (SI) \\
\hline $181-560$ days of age & 9 bulls & 10 bulls & 10 bulls \\
\hline
\end{tabular}

${ }^{1} 135 \mathrm{~g} / 11$ water; liquid feed: $15.8 \mathrm{MJ}$ metabolizable energy, $21 \%$ protein, $10 \%$ fat, $30 \%$ lactose, $1.20 \%$ crude fiber, $1.45 \%$ lysine, $0.40 \%$ methionine, $0.90 \% \mathrm{Ca}, 0.55 \% \mathrm{P}, 0.10 \% \mathrm{Mg}, 108 \mathrm{mg} / \mathrm{kg} \mathrm{Zn}, 140 \mathrm{mg} / \mathrm{kg} \mathrm{Fe}$, $12 \mathrm{mg} / \mathrm{kg} \mathrm{Cu}, 1.20 \mathrm{mg} / \mathrm{kg} \mathrm{I}, 1.20 \mathrm{mg} / \mathrm{kg} \mathrm{Co}, 0.33 \mathrm{mg} / \mathrm{kg} \mathrm{Se}, 46000 \mathrm{IU}$ vitamin A, D $4500 \mathrm{IU}$ vitamin D, $100 \mathrm{IU}$ vitamin E, C 150 IU vitamin C.

${ }^{2}$ starter diet: $6.25 \mathrm{MJ}$ net energy, $24 \%$ total protein, $7.5 \%$ crude fiber, $1.30 \% \mathrm{Ca}, 0.70 \% \mathrm{P}, 0.40 \% \mathrm{Na}, 0.30 \%$ $\mathrm{Mg}, 335000 \mathrm{IU}$ vitamin A, $6700 \mathrm{IU}$ vitamin D, $260 \mathrm{mg} / \mathrm{kg}$ vitamin $\mathrm{E}$.

Silage was made in concrete horizontal silos, from a mixture of first-cut grasses harvested at the end of the heading stage. Farm-grown triticale grain was used, and rapeseed meal (RSM) was purchased from an oil processing plant. All feed samples were assayed for the content of basic nutrients - with standard methods (AOAC 2005), NDF, ADF and ADL - with the method of Van Soest et al. (1991). Silage samples were assayed for: $\mathrm{pH}$ - with the HI $8314 \mathrm{pH}$-meter, concentrations of lactic acid, acetic acid and butyric acid in water extract - by high-performance liquid chromatography (HPLC) with the Shimadzu system and a Varian MetaCarb 67H column, and the content of water-soluble carbohydrates - by the anthrone method (Thomas, 1977), protein nitrogen (N-protein) - with the use of trichloroacetic acid (TCA), and ammonia nitrogen $\left(\mathrm{N}_{-} \mathrm{NH}_{3}\right)$ - by the Conway method (Licitra et al., 1996). Amino acid nitrogen was calculated based on the number of free amino acids which were determined with the AAA 400 INGOS automatic amino acid analyzer (Czech Republic) with the use of a lithium column after deproteinization of TCA samples.

No disease cases were recorded during fattening. After the completion of fattening, the animals were transported to a meat processing plant where they were kept in individual boxes with access to water for 15 to $20 \mathrm{~h}$, and subsequently slaughtered. 
Table 2. Chemical composition and nutritional value of experimental diets (mean \pm standard error of the mean)

\begin{tabular}{|c|c|c|c|c|c|}
\hline Item & Silage & Triticale & Rapeseed meal & Concentrate I & Concentrate II \\
\hline Dry matter (g) & $397 \pm 0.91$ & $881 \pm 0.96$ & $887 \pm 0.68$ & $883.9 \pm 1.12$ & $885.5 \pm 1.27$ \\
\hline \multicolumn{6}{|c|}{ On dry matter basis $\left(\mathrm{g} \cdot \mathrm{kg}^{-1}\right)$} \\
\hline organic matter & $920 \pm 2.46$ & $981 \pm 0.95$ & $927 \pm 1.05$ & $928 \pm 1.14$ & $921 \pm 1.39$ \\
\hline crude protein & $141 \pm 1.48$ & $133 \pm 1.32$ & $388 \pm 1.39$ & $191 \pm 1.15$ & $175 \pm 1.13$ \\
\hline NDF & $569 \pm 5.31$ & $193 \pm 1.63$ & $310 \pm 0.68$ & $214 \pm 1.21$ & $205 \pm 1.92$ \\
\hline $\mathrm{ADF}$ & $387 \pm 0.92$ & $44 \pm 0.65$ & $228 \pm 0.67$ & $88 \pm 1.85$ & $76 \pm 1.22$ \\
\hline UFV & $0.80 \pm 0.03$ & $1.21 \pm 0.33$ & $1.01 \pm 0.05$ & $1.11 \pm 0.03$ & $1.12 \pm 0.02$ \\
\hline PDIN & $82.2 \pm 1.64$ & $89 \pm 0.38$ & $259 \pm 0.57$ & $127.2 \pm 0.41$ & $116.4 \pm 1.23$ \\
\hline PDIE & $69.5 \pm 0.58$ & $109 \pm 1,03$ & $163 \pm 1.56$ & $118.6 \pm 1.26$ & $113.1 \pm 1.71$ \\
\hline
\end{tabular}

$\mathrm{N}=9$ for silage; $\mathrm{N}=5$ for triticale and rapeseed meal; $\mathrm{N}=7$ for concentrates.

Fermentation characteristics of silage: $\mathrm{pH} 4.8 \pm 0.3$; lactic acid, $5.4 \pm 2.0 \%$ dry matter; volatile fatty acids, $2.7 \pm 0.5 \%$ dry matter; water-soluble carbohydrates, $8.2 \pm 4.8 \%$ dry matter; $\mathrm{NNH}_{3} \% \mathrm{~N}, 10.3 \pm 6.7$; true protein $51.8 \pm 4.6 \%$ crude protein.

NDF - neutral detergent fiber; ADF - acid detergent fiber; UFV - Meat Production Units; PDIN - protein digested in the small intestine depending on rumen degraded protein; PDIE - protein digested in the small intestine depending on rumen fermented organic matter.

Table 3. Chemical composition and nutritional value of experimental TMR (mean \pm standard error of the mean)

\begin{tabular}{lccccc}
\hline \multicolumn{1}{c|}{ Item } & $\mathrm{I}<300 \mathrm{~kg} \mathrm{BW}$ & $\mathrm{SI}<300 \mathrm{~kg}$ BW & $\mathrm{I}>300 \mathrm{~kg}$ BW & SI $>300 \mathrm{BW}$ \\
\hline Grass silage (\% DM in diets) & 60 & 75 & 60 & 75 \\
Concentrate I (\% DM in diets) & 40 & 25 & & \\
Concentrate II (\% DM in diets) & & & 40 & 25 \\
DM (g) & $577.1 \pm 0.69$ & $509.6 \pm 0.78$ & $573.1 \pm 0.91$ & $514.6 \pm 0.95$ \\
On DM basis ( $\left.\mathrm{g} \cdot \mathrm{kg}^{-1}\right)$ & & & & \\
crude protein & $161 \pm 1.34$ & $153 \pm 1.23$ & $154 \pm 1.21$ & $149 \pm 1.18$ \\
NDF & $416 \pm 4.98$ & $472 \pm 1.56$ & $402 \pm 2.21$ & $463 \pm 3.01$ \\
ADF & $185 \pm 0.98$ & $311 \pm 0.89$ & $169 \pm 1.23$ & $295 \pm 2.09$ \\
UFV & $0.93 \pm 0.03$ & $0.88 \pm 0.09$ & $0.93 \pm 0.04$ & $0.88 \pm 0.03$ \\
PDIN & $100.4 \pm 1.24$ & $93.6 \pm 0.45$ & $96.1 \pm 0.51$ & $90.8 \pm 1.03$ \\
PDIE & $88.9 \pm 1.36$ & $81.6 \pm 1.08$ & $87.2 \pm 1.81$ & $80.6 \pm 1.63$ \\
\hline
\end{tabular}

I - intensive fattening; SI - semi-intensive fattening; BW - body weight; DM - dry matter; NDF - neutral detergent fiber; ADF - acid detergent fiber; UFV - meat fodder units; PDIN - protein digested in the small intestine when rumen fermentable $\mathrm{N}$ is limiting; PDIE - protein digested in the small intestine when rumen fermentable energy is limiting.

\section{Carcass characteristics}

The animals were weighed before slaughter, stunned, bled, dressed, and split into two sides that were then chilled for $96 \mathrm{~h}$ at $4^{\circ} \mathrm{C}$. Electrical stimulation was not applied to the carcasses. Half-carcasses were weighed within an accuracy of $0.5 \mathrm{~kg}$, using 
an automatic in-line scale. Carcass conformation and fatness were evaluated based on the EUROP system criteria by a trained grader (Kien, 2004). Dressing percentage (percentage ratio of carcass weight to slaughter weight) was calculated. Ninety-six hours after slaughter, three-rib sections (10th-12th ribs) were taken from the right side carcasses by making two cuts perpendicular to the spine along the entire carcass between the 9th-10th and 12th-13th thoracic vertebrae, and then the carcasses were cut into primal cuts in accordance with Polish Standard PN-88/A-82003. The percentages of shoulder, fore ribs, best ribs, sirloin, and round of beef ( 5 most valuable primal cuts) and tenderloin from the right carcass were calculated. The percentages of soft tissues (meat, fat and tendons) and bones were determined in three-rib sections. The area of the longissimus thoracis et lumborum (LT) muscle was determined between the 12th and 13th thoracic vertebrae. A muscle sample was pressed onto filter paper and the area was measured with a planimeter. After $96 \mathrm{~h}$ of carcass chilling, samples weighing approximately $200 \mathrm{~g}$ were taken from the LT muscle between the 11th and 13th thoracic vertebrae. Vacuum-packaged samples were transported $\left(+4^{\circ} \mathrm{C}\right)$ to the laboratory. Fat was extracted from ground meat samples by the Soxhlet method using the Büchi B-811 extraction system (Büchi Labortechnik AG, Flawil, Switzerland), with hexane as a solvent.

\section{Statistical analysis}

The data were analyzed statistically using Statistica version 12.0 software (StatSoft, 2015). The rearing period was evaluated by one-way ANOVA with rearing systems as experimental factors (MF and $\mathrm{NC}$ ). The effects of rearing system (MF and $\mathrm{NC}$ ) and fattening intensity (I and SI) on fattening performance and carcass characteristics were determined by the least squares method using the formula:

$$
Y_{i j k}=\mu+A_{i}+B_{j}+(A B)_{i j}+e_{i j k}
$$

where: $Y_{i j k}$ is the value of the analyzed parameter, $\mu$ is population mean, $A_{i}$ is the effect of rearing system $(1,2), B_{j}$ is the effect of fattening intensity $(1,2),(A B)_{i j}$ is the rearing system $\times$ fattening intensity interaction, and $e_{i j k}$ is random error.

\section{Results}

\section{Calf rearing and fattening performance}

The average daily gain of calves during the rearing period was 0.8 to $1 \mathrm{~kg}$, and it was $17.7 \%$ higher $(\mathrm{P} \leq 0.01)$ in the $\mathrm{NC}$ group than in the MF groups (Table 4). As a result, the average BW of the NC calves was $21.6 \mathrm{~kg}$ higher compared to the MF calves.

No significant interactions were found between rearing system and fattening intensity for BW, daily gain, feed intake or feed conversion ratio during the fattening period (Table 5).

Intensively fattened bulls had $25 \%$ higher average daily gain compared to the SI bulls during the fattening period $(\mathrm{P}<0.001)$. In MF group bulls fattened intensively, 
average daily gain was $0.156 \mathrm{~kg}$ higher during fattening than during rearing. Intensively fattened bulls had higher average daily dry matter (DM), net energy and crude protein intake compared to the SI bulls (Table 5).

Table 4. Characteristics of calves during the rearing period

\begin{tabular}{l|c|c|cc}
\hline \multirow{2}{*}{\multicolumn{1}{c|}{ Item }} & \multicolumn{2}{c|}{ Rearing system } & \multirow{2}{*}{ SEM } & \multirow{2}{*}{ P-value } \\
\cline { 2 - 3 } & $\mathrm{MF}$ & $\mathrm{NC}$ & & \\
\hline BW at birth (kg) & 38.1 & 38.3 & 0.284 & 0.917 \\
Age at weaning (days) & 149.4 & 148.5 & 0.363 & 0.605 \\
BW at weaning (kg) & 164.5 & 186.1 & 2.088 & 0.000 \\
Average daily gain during the rearing period $(\mathrm{kg})$ & 0.846 & 0.996 & 0.014 & 0.000 \\
\hline
\end{tabular}

MF - milk feeder; NC - nurse cow; SEM - standard error of the mean; BW - body weight.

Table 5. Effects of rearing system and fattening intensity on the fattening performance of young bulls

\begin{tabular}{|c|c|c|c|c|c|c|c|c|}
\hline \multirow{2}{*}{ Item } & \multicolumn{2}{|c|}{ MF } & \multicolumn{2}{|c|}{$\mathrm{NC}$} & \multirow{2}{*}{ SEM } & \multicolumn{3}{|c|}{ P-value } \\
\hline & I & SI & I & SI & & RS & FI & $\mathrm{RS} \times \mathrm{FI}$ \\
\hline $\begin{array}{l}\text { Age at the beginning of fattening } \\
\text { (days) }\end{array}$ & 181.3 & 182 & 182.3 & 179.8 & 0.331 & 0.300 & 0.151 & 0.121 \\
\hline $\begin{array}{l}\text { BW at the beginning of fattening } \\
(\mathrm{kg})\end{array}$ & 185.8 & 185.4 & 204.8 & 205.4 & 2.056 & 0.000 & 0.956 & 0.827 \\
\hline Age at the end of fattening (days) & 558.2 & 560.9 & 556.5 & 556.4 & 1.688 & 0.397 & 0.696 & 0.670 \\
\hline $\mathrm{BW}$ at the end of fattening $(\mathrm{kg})$ & 563.6 & 466.1 & 586.8 & 537.3 & 12.18 & 0.020 & 0.001 & 0.218 \\
\hline Daily gain during fattening $(\mathrm{kg})$ & 1.002 & 0.741 & 1.022 & 0.882 & 0.030 & 0.102 & 0.000 & 0.213 \\
\hline $\begin{array}{l}\text { Average daily gain from birth to } \\
\text { slaughter }(\mathrm{kg})\end{array}$ & 0.941 & 0.763 & 0.987 & 0.897 & 0.022 & 0.013 & 0.000 & 0.204 \\
\hline Daily intake (kg DM) & 8.52 & 7.64 & 8.71 & 8.33 & 0.236 & 0.326 & 0.043 & 0.658 \\
\hline Daily silage intake (kg DM) & 5.11 & 5.73 & 5.23 & 6.24 & 0.223 & 0.365 & 0.032 & 0.952 \\
\hline Daily net energy intake (UFV) & 7.92 & 6.72 & 8.1 & 7.33 & 0.213 & 0.365 & 0.031 & 0.635 \\
\hline Daily crude protein intake (g) & 1371 & 1169 & 1341 & 1241 & 14.35 & 0.341 & 0.043 & 0.753 \\
\hline FCR & 9.03 & 9.96 & 8.81 & 9.28 & 0.321 & 0.389 & 0.078 & 0.678 \\
\hline
\end{tabular}

MF - milk feeder; NC - nurse cow; I - intensive fattening; SI - semi-intensive fattening;

SEM - standard error of the mean; RS - rearing system; FI - fattening intensity; BW - body weight; FCR feed conversion ratio, $\mathrm{kg}$ [DM/kg daily gain].

Rearing systems had no effect on average daily gain or feed intake during the fattening period.

\section{Carcass characteristics}

No significant interactions were found between rearing system and fattening intensity for carcass characteristics or the tissue composition of three-rib sections (Tables 6 and 7). The average BW of NC group bulls before slaughter was significantly higher compared with MF group bulls $(\mathrm{P}<0.05)$, but rearing system had no 
significant effect on any other carcass parameters or the tissue composition of threerib cuts. Average BW before slaughter, similarly to BW at the end of fattening, was significantly higher in intensively fattened bulls than in semi-intensively fattened animals. Half-carcass weight of the I bulls was higher compared to the carcasses of the SI bulls. Carcass dressing percentage was higher $(\mathrm{P} \leq 0.05)$ in intensively fattened bulls. The positive effect of intensive feeding on carcass fat content was statistically significant. LT area was greater $(\mathrm{P} \leq 0.01)$ in the carcasses of intensively fattened bulls, in comparison with semi-intensively fattened animals. The intramuscular fat (IMF) content of LT was higher $(\mathrm{P} \leq 0.01)$ in the I group than in the SI group (Table 6 ). The tissue composition of three-rib cuts varied significantly between groups I and SI. The three-rib cuts from the carcasses of intensively fattened bulls had significantly higher fat content and lower bone content, compared with the carcasses of semi-intensively fattened animals.

Table 6. Carcass characteristics

\begin{tabular}{|c|c|c|c|c|c|c|c|c|}
\hline \multirow{2}{*}{ Item } & \multicolumn{2}{|c|}{ MF } & \multicolumn{2}{|c|}{$\mathrm{NC}$} & \multirow{2}{*}{ SEM } & \multicolumn{3}{|c|}{ P-value } \\
\hline & I & SI & I & SI & & RS & FI & $\mathrm{RS} \times \mathrm{FI}$ \\
\hline Numbers & 9 & 9 & 10 & 10 & & & & \\
\hline BW before slaughter $(\mathrm{kg})$ & 545.3 & 447.5 & 560.3 & 510.8 & 11.32 & 0.021 & 0.001 & 0.226 \\
\hline Hot carcass weight $(\mathrm{kg})$ & 316.3 & 255.8 & 325.9 & 291.7 & 7.160 & 0.121 & 0.001 & 0.223 \\
\hline Dressing percentage & 58.00 & 57.18 & 58.20 & 57.10 & 0.351 & 0.351 & 0.044 & 0.880 \\
\hline${ }^{\mathrm{a} C}$ Conformation score (pts) & 7.4 & 7.0 & 8.1 & 7.2 & 0.245 & 0.446 & 0.133 & 0.446 \\
\hline${ }^{\mathrm{b}}$ Fatness score (pts) & 7.1 & 5.9 & 7.4 & 6.0 & 0.430 & 0.831 & 0.043 & 0.943 \\
\hline $\begin{array}{l}\text { 'Share of } 5 \text { most valuable primal } \\
\text { cuts in the half-carcass (\%) }\end{array}$ & 62.42 & 62.12 & 62.90 & 62.44 & 0.232 & 0.612 & 0.890 & 0.958 \\
\hline $\begin{array}{l}\text { Longissimus thoracis et lumborum } \\
\text { area }\left(\mathrm{cm}^{2}\right)\end{array}$ & 91.8 & 78.9 & 97.4 & 83.9 & 2.327 & 0.205 & 0.003 & 0.940 \\
\hline Intramuscular fat (\%) & 2.92 & 1.74 & 3.03 & 1.94 & 0.280 & 0.777 & 0.002 & 0.733 \\
\hline
\end{tabular}

$\mathrm{MF}$ - milk feeder; NC - nurse cow; I - intensive fattening; SI - semi-intensive fattening;

SEM - standard error of the mean; RS - rearing system; FI - fattening intensity; BW - body weight;

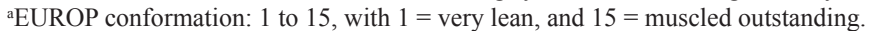

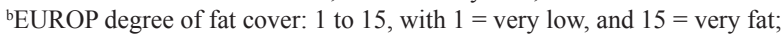

c5 most valuable primal cuts: shoulder, fore ribs, best ribs, sirloin, round.

Table 7. Tissue composition of 3-rib sections

\begin{tabular}{|c|c|c|c|c|c|c|c|c|}
\hline \multirow{2}{*}{ Item } & \multicolumn{2}{|c|}{ MF } & \multicolumn{2}{|c|}{$\mathrm{NC}$} & \multirow{2}{*}{ SEM } & \multicolumn{3}{|c|}{ P-value } \\
\hline & I & SI & $\mathrm{I}$ & SI & & RS & FI & $\mathrm{RS} \times \mathrm{FI}$ \\
\hline 3-rib sections $(\mathrm{kg})$ & 8.11 & 6.50 & 8.51 & 7.35 & 0.245 & 0.155 & 0.003 & 0.603 \\
\hline \multicolumn{9}{|l|}{ 3-rib sections (\%): } \\
\hline fat & 26.02 & 21.72 & 28.11 & 21.47 & 1.326 & 0.723 & 0.043 & 0.653 \\
\hline muscles & 50.64 & 52.01 & 49.81 & 52.94 & 0.860 & 0.977 & 0.121 & 0.618 \\
\hline bones & 18.88 & 21.14 & 18.52 & 21.20 & 0.571 & 0.891 & 0.034 & 0.853 \\
\hline tendons & 4.46 & 4.63 & 3.21 & 4.39 & 0.218 & 0.078 & 0.107 & 0.226 \\
\hline
\end{tabular}

$\mathrm{MF}$ - milk feeder; $\mathrm{NC}$ - nurse cow; I - intensive fattening; SI - semi-intensive fattening;

SEM - standard error of the mean; RS - rearing system; FI - fattening intensity. 


\section{Discussion}

\section{Calf rearing and fattening performance}

The differences in daily gain during the rearing period were influenced by the feeding regimen: NC group calves had unlimited and direct access to fresh milk, whereas MF group calves were fed restricted amounts of milk replacer. Wagenaar and Langhout (2006) demonstrated that the average BW of dairy calves reared in a suckling system reached $136.7 \mathrm{~kg}$ at weaning (90 days of age) compared with $90.4 \mathrm{~kg}$ in calves that were bucket-fed milk replacer. The growth performance of calves is also affected by supplementary feed provided in addition to liquid feed. In a study by Reddy et al. (2017), calves fed maternal milk supplemented with timothy (Phleum pratense) hay up to 10 weeks of age were characterized by $0.050 \mathrm{~kg}$ higher BW gain, in comparison with calves fed milk replacer and high-energy concentrate. In the current experiment, calves of both groups (NC and MF) were fed identical concentrate. The growth rate of calves is also influenced by their health status. In the present study, a higher incidence of disease was noted in calves kept in group pens and fed milk replacer, compared with nursed calves. Wagenaar and Langhout (2006) also reported more cases of diarrhea in calves fed milk replacer. A decrease in the BW gain of sick animals, compared with their healthy counterparts, was also observed by Gardner et al. (1999). However, Roeber et al. (2001) and Thompson et al. (2006) demonstrated that the average daily gains of animals with bovine respiratory disease (BRD) were comparable, higher or lower than those of healthy animals. The health status and BW gain of calves are influenced not only by the type of liquid feed but also by the feeding method. Boonbrahm et al. (2004) found that calves that were allowed to suckle their mothers twice daily were characterized by $35 \%$ higher BW gain and a lower mortality rate than bucket-reared calves. According to Huuskonen et al. (2011), the BW gain of calves fed milk replacer can be increased by feeding acidified milk at the end of the rearing period.

In intensively fattened NC bulls, average daily gain increased by only $0.026 \mathrm{~kg}$, which points to compensatory growth in the I (MF) group. According to Greenwood et al. (2006), cattle grown slowly from birth to weaning exhibit incomplete compensation and remain smaller during rearing to 30 months of age. Compensatory growth was also observed by Hennessy et al. (2001). Beef calves with lower growth rates during the nursing period, which were lighter at weaning, had higher BW gains after weaning than calves with higher pre-weaning growth rates, which were heavier at weaning.

Higher BW and average daily gain of cattle as a result of increased energy value of fodder was also reported by Therkildsen et al. (2008). Average energy intake during fattening was higher than the energy requirements of bulls produced by crossing dairy cows with Charolais and Simmental bulls (INRA). The above differences resulted from higher intake of roughage-based diets by Hereford crosses. Our previous study, which compared the fattening performance of PHF $\times$ Limousin, PHF $\times$ Charolais and PHF $\times$ Hereford crosses, revealed higher intake of diets based on grass silage by PHF $\times$ Hereford bulls, relative to the remaining crossbred bulls (Purwin et al., 2016). It appears that higher BW gain in intensively fattened bulls was 
due to higher total DM intake and higher energy concentration per kg of diet DM. In the current study, a higher proportion of concentrate in the ration contributed to an increase in DM intake by $12 \%$ in the MF group and by $5 \%$ in the $\mathrm{NC}$ group. As a result, net energy intake increased by $18 \%$ and $11 \%$, respectively, whereas total protein intake increased by $17 \%$ and $9 \%$, respectively. The above findings confirm that the increased amount of concentrate in the diet is accompanied by an increase in total DM intake and a decrease in silage intake (Kirkland and Patterson, 2006). In a study by Huuskonen et al. (2007), bulls were fed grass silage with 30\%, 50\% and $70 \%$ of concentrate. The cited authors reported a linear growth response of bulls to the increased proportion of concentrate in the ration.

\section{Carcass characteristics}

In our study, carcass dressing percentage was higher in intensively fattened bulls. In previous studies including young bulls (Nogalski et al., 2014 b) and steers (Nogalski et al., 2014 a), intensive fattening also increased carcass dressing percentage. Beef carcasses receive higher conformation and fat cover scores when cattle are raised under intensive feeding systems, which was also observed in the present study. Carcass conformation scores increase with increasing body weight before slaughter (Nogalski et al., 2014 a) and feeding intensity (Nogalski et al., 2014 b). The LT muscle and five primal cuts are high-value sections of the beef carcass, associated with lean meat content (Nogalski et al., 2013). In our study, LT area was greater in the carcasses of intensively fattened bulls whose carcasses had better conformation. In our study, the effect of the rearing system (rate of growth) on the proportion of five primal cuts and LT area was not significant. In contrast, Greenwood et al. (2006) found that cattle grown slowly from birth to weaning had smaller carcasses and yielded less beef at 30 months of age. However, when compared at equivalent carcass weights, the cattle restricted in growth from birth to weaning yielded slightly more beef and were leaner than their rapidly grown counterparts. In our study, the IMF content of LT was higher in intensively fattened bulls. Mezgebo et al. (2017) reported that high dietary inclusion levels of ground grain had a beneficial influence on IMF content. The level of IMF at the beginning of the growth period is likely to be a key determinant of the final level of IMF after finishing. This is associated with the fact that adipose tissue begins to accumulate in the early weaning period (Hocquette et al., 2010). A tendency to accumulate an increased amount of IMF in the Longissimus dorsi muscle as a result of increased energy value of cattle feed was also reported by Therkildsen et al. (2008). Similarly to the present experiment involving young bulls, Franco and Lorenzo (2014) demonstrated that feeding intensity affected the content of IMF, but not DM or protein in foal muscles. Schoonmaker et al. (2003) reported that high-concentrate feed offered ad libitum improved IMF deposition in early-weaned steers during the growing stage; however, fat deposition rates were lower when the animals were fed the same diet in the finishing period. In our study, the difference in IMF content between the rearing systems was small and non-significant. Greenwood et al. (2006) also found that the rearing system had no effect on the IMF content of Longissimus dorsi. 
Tissue composition is an important determinant of beef carcass quality. Carcasses with the highest muscle content and optimal fat content are regarded as most desirable (Kołczak, 2008). In our study, the rearing system had no effect on the tissue composition of three-rib cuts at the end of fattening. Hennessy et al. (2001) concluded that cattle from low pre-weaning nutrition groups generally have less fat than those from high pre-weaning nutrition groups, although if compared at a constant carcass weight, differences in fatness may not be evident. Calves with lower weaning weights take longer to reach carcass specifications than heavier calves. In contrast to the above findings relating to body and carcass composition, severe nutritional restriction to weaning followed by concentrate (high energy) feeding from weaning to slaughter results in increased fatness at the same live and carcass weights compared with cattle well-nourished before weaning (Tudor et al., 1980).

In conclusion, beef calves can be raised in a suckling system with nurse cows. In comparison with calves fed milk replacer from automated stations, nursed calves are healthier and have higher BW gain, which is a good starting point for fattening. A higher proportion of concentrate in the ration had a beneficial influence on the fattening performance and carcass characteristics of bulls. The LT of intensively fattened bulls had higher IMF content.

\section{Conflict of interest statement}

We confirm that there are no known conflicts of interest associated with this publication and there has been no significant financial support for this work that could have influenced its outcome.

\section{References}

AOAC (2005). Association of Official Analytical Chemists. Official Methods of Analysis. 18th Edition, Arlington.

Bernal-Rigoli J.C., Allen J.D., Marchello J.A., Cuneo S.P., Garcia S.R., Xie G., Hall L.W., Burrows C.D., Duff G.C. (2012). Effects of housing and feeding systems on performance of neonatal Holstein bull calves. J. Anim. Sci., 90: 2818-2825.

B o o n bra h m N., P e ter s K.J., K i j or a C. (2004). The influence of calf rearing methods and milking methods on performance traits of crossbred dairy cattle in Thailand. 3. Calf performance. Arch. Tierz., 47: 405-414.

B ure s D., B arton L. (2012). Growth performance, carcass traits and meat quality of bulls and heifers slaughtered at different ages. Czech J. Anim. Sci., 57: $34-43$.

Franco D., L orenzo J.M. (2014). Effect of muscle and intensity of finishing diet on meat quality of foals slaughtered at 15 months. Meat Sci., 96: 327-334.

Gardner B.A., Dolezal H.G., Bryant L.K., Owens F.N., S mith R.A. (1999). Health of finishing steers: Effects on performance, carcass traits, and meat tenderness. J. Anim. Sci., 77: 3168-3175.

Greenw o od P.L., C a fe L.M., Hearns haw H., Henness y D.W., Thomps on J.M., M or r i s S.G. (2006). Long-term consequences of birth weight and growth to weaning on carcass, yield and beef quality characteristics of Piedmontese- and Wagyu-sired cattle. Aust. J. Exp. Agric., 46: $257-269$.

He a rn s haw H. (1997). Effect of pre-weaning nutrition on post-weaning growth, carcase and meat quality traits. In: Growth and development of cattle. Proceedings of the growth and development 
workshop, Hennessy D.W., McLennan S.R., Oddy V.H. (eds). Cattle and Beef Industry Co-operative Research Centre (Meat Quality), University of New England, Armidale, N.S.W., pp. 59-67.

Henness y D.W., Morris S.G., A $11 \mathrm{ingham} \mathrm{P.G.} \mathrm{(2001).} \mathrm{Improving} \mathrm{the} \mathrm{pre-weaning} \mathrm{nutrition}$ of calves by supplementation of the cow and/or the calf while grazing low quality pastures. 2. Calf growth, carcass yield and eating quality. Aust. J. Exp. Agric., 41: 715-724.

H o c que t t e J.F., Gondret F., B a e z a E., M e d a l e F., Jurie C., P e th i c k D.W. (2010). Intramuscular fat content in meat producing animals: Development, genetic and nutritional control, and identification of putative markers. Animal, 4: 303-319.

Huuskonen A., Khalili H., Joki-Tokola E. (2007). Effects of three different concentrate proportions and rapeseed meal supplement to grass silage on animal performance of dairy breed bulls with TMR feeding. Livest. Sci., 110: 154-165.

Huu s k on en A., H u u m on en M., Jok i - Tok ol a E., Tu o m is to L. (2011). Effects of different liquid feeding strategies during the pre-weaning period on the performance and carcass characteristics of dairy bull calves. Acta Agr. Scand. A-An., 61: 187-195.

Huuskonen A., Pes onen M., Kämäräinen H., Kauppinen R. (2014). Production and carcass traits of purebred Nordic Red and Nordic Red $\times$ beef breed crossbred bulls. J. Agric. Sci., 152: 504-517.

K i e n S. (2004). The classification of carcass of adult bovine animals in the EUROP. Meat and Fat Research Institute, Warsaw, Division in Poznań, Poland.

K irk land R.M., P a tters on D.C. (2006). The effect of quality of grass and maize silage on the intake and performance of beef cattle. Livest. Sci., 100: 179-188.

Klein-Joebst 1 D., Tim A., Sturml e chner F., I wersen M., Drillich M. (2015). Results of an online questionnaire to survey calf management practices on dairy cattle breeding farms in Austria and to estimate differences in disease incidences depending on farm structure and management practices. Acta Vet. Scand., Article Number: 44.

K ołc zak T. (2008). Beef quality (in Polish). Żywność. Nauka. Technologia. Jakość, 1: 5-22.

Li c itra G., Hernandez T.M., Van S o es t P.J. (1996). Standardization of procedures for nitrogen fractionation of ruminant feeds. Anim. Feed Sci. Technol., 57: 347-358.

Maccari P., Wiedemann S., Kunz H.J., Kaske M. (2015). Effects of two different rearing protocols for Holstein bull calves in the first 3 weeks of life on health status, metabolism and subsequent performance. J. Anim. Physiol. Anim. Nutr., 99: 737-746.

M e z g e bo G.B., Molon e y A.P., O 'R i ordan E.G., M c Ge e M., R i c hard s o n R.I. Mo n a h a n F.J. (2017). Comparison of organoleptic quality and composition of beef from suckler bulls from different production systems. Animal, 11: 538-546.

Nogalski Z., Wroński M., Wielgosz-Groth Z., Purwin C., Sobczuk-Szul M., Mochol M., P o g or z els k a P. (2013). The effect of carcass conformation class (EUROP system) on the slaughter quality of young crossbred beef bulls and Holstein-Friesians. Ann. Anim. Sci., 13: $23-28$.

Nogalski Z., Wielgosz-Groth Z., Purwin C., Sobczuk-Szul M., Mochol M., Pogorzelska-Przybylek P., Winarski R. (2014 a). Effect of slaughter weight on the carcass value of young crossbred ('Polish Holstein Friesian' $\times$ 'Limousin') steers and bulls. Chilean J. Agric. Res., 74: 59-66.

Nogalski Z., Wielgosz-Groth Z., Purwin C., Nogalska A., Sobczuk-Szul M., W in ar s ki R., P o g or ze ls k a P. (2014 b). The effect of slaughter weight and fattening intensity on changes in carcass fatness in young Holstein-Friesian. Ital. J. Anim. Sci., 13: 66-72.

Purwin C., Wy zli c I., Wi elgosz-Groth Z., S obczuk-Szul M., Mi chalski J.P., Nog a ls k i Z. (2016). Fattening performance of crossbred (Polish Holstein-Friesian $\times$ Hereford, Limousin or Charolais) bulls and steers offered high-wilted grass silage-based rations. Chilean J. Agric. Res., 76: 337-342.

R e d d y K.E., J e ong J.Y., B a e k Y-C., O h Y.K., K i m M., S o K.M., K i m M.J., K i m D. W., P a r k S.K., L e e H.J. (2017). Early weaning of calves after different dietary regimens affects later rumen development, growth, and carcass traits in Hanwoo cattle. Asian-Australas. J. Anim. Sci., 30: 1425-1434.

Roeber D.L., Speer N.C., Gentry J.G., Tatum J.D., Smith C.D., Whittier J.C., P a s G.F., Jon e s K., B elk E., S mith G.C. (2001). Feeder cattle health management: Effects 
on morbidity rates, feedlot performance, carcass characteristics, and beef palatability. Prof. Anim. Sci., 17: 39-44.

S c ho o n m a r k e r J.P.,C e c a v a M.J.,F a u 1 kn e r F.L.,F 1 u h a r t y F.L.,Z e r b y H.N.,L o e r c h S.C. (2003). Effect of source of energy and rate of growth on performance, carcass characteristics, ruminal fermentation, and serum glucose and insulin of early-weaned steers. J. Anim. Sci., 81: 843-855.

The rkil d s e n M., H o u b a k M.B., B y r n e D.V. (2008). Feeding strategy for improving tenderness has opposite effects in two different muscles. Meat Sci., 80: 1037-1045.

T h o m a s A.T. (1977). An automated procedure for the determination of soluble carbohydrates in herbage. J. Sci. Food Agric., 28: 639-642.

Th o m p s on P.N., S t on e A., S c hult he is s W.A. (2006). Use of treatment records and lung lesion scoring to estimate the effect of respiratory disease on growth during early and late finishing periods in South African feedlot cattle. J. Anim. Sci., 84: 488-498.

Tud or G.D., Utting D.W., O'R o u rke P.K. (1980). The effect of pre- and postnatal nutrition on the growth of beef cattle. III. The effect of severe restriction in early postnatal life on the development of the body components and chemical composition. Aust. J. Agric. Res., 31: 191-204.

Vaars t M., J en s en M.B., S a n d a ge r A.M. (2001). Behaviour of calves at introduction to nurse cows after the colostrum period. Appl. Anim. Behav. Sci., 73: 27-33.

Van S o e s t P.J., R o be r t s o n J.B., L e w is B.A. (1991). Methods for dietary fiber, neutral detergent fiber and nonstarch polysaccharides in relation to animal nutrition. J. Dairy Sci., 74: 3583-3597.

Wa ge na ar J.P., L a n g h o u t J. (2006). The potential of suckling systems in calf rearing in Dutch organic dairy farming, practical implementation and liveweight development. In: Proc. 1st IFOAM Conference on Animals in Organic Production, 23-25.08.2006, St. Paul, Minnesota, International Federation of Organic Agriculture Movements (IFOAM), Bonn, pp. 64-71.

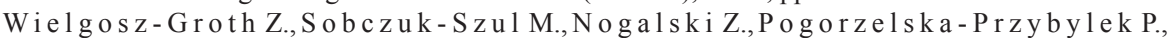
Purwin C. (2017). Effect of health status on fattening performance in young crossbred Polish Holstein-Friesian $\times$ Limousin Bulls and steers. Anim. Sci. J., 88: 1012-1020.

Wolcott M.L., Gras er H.U., Johns to n D.J. (2010). Effects of early weaning on growth, feed efficiency and carcass traits in Shorthorn cattle. Anim. Prod. Sci., 50: 315-321.

Received: 8 XI 2017

Accepted: 25 IV 2018 